\title{
Polemika
}

DOI: $10.14746 /$ por.2018.1.22

\section{O NIEKTÓRYCH ASPEKTACH TRADYCJI CZYTANIA I PRZEKŁADANIA LITERATURY DLA DZIECI. NA KANWIE RECENZJI KSIĄŻKI JOANNY DYBIEC- -GAJER, ZŁOTA RÓŻDŻKA - OD KSIĄŻKI DLA DZIECI PO DRESZCZOWIEC RACZEJ DLA DOROSEYCH}

\author{
Eliza Pieciul-KarmińsKa ${ }^{1}$
}

Joanna Dybiec-Gajer. Złota różdżka - od książki dla dzieci po dreszczowiec raczej dla dorostych. Kraków: Tertium, 2017. 214 S.

\footnotetext{
Słowa kluczowe: Heinrich Hoffmann, Złota różdżka, baśnie braci Grimm, literatura dziecięca w przekładzie

Keywords: Heinrich Hoffmann, Struwwelpeter, Grimm's Fairy Tales, children's literature in translation
}

\begin{abstract}
Abstrakt: Eliza Pieciul-Karmińska, O NIEKTÓRYCH ASPEKTACH TRADYCJI CZYTANIA I PRZEKŁADANIA LITERATURY DLA DZIECI. NA KANWIE RECENZJI KSIĄŻKI JOANNY DYBIEC-GAJER, ZŁOTA RÓŻDŻKA - OD KSIĄŻKI DLA DZIECI PO DRESZCZOWIEC RACZEJ DLA DOROSŁYCH. „PORÓWNANIA” 1 (22), 2018. T. XXII, S. 383-397. ISSN 1733-165X. Artykuł poświęcony jest recenzji książki Joanny Dybiec-Gajer pt. Złota różḋ̇ka - od ksiażki dla dzieci po dreszczowiec raczej dla dorostych (Kraków 2017), w której autorka analizuje polską historię przekładu i recepcji światowego bestselleru Heinricha Hoffmanna pt. Struwwelpeter. W dalszej części artykułu zaprezentowany został nowy polski przekład dzieła Hoffmanna pt. Złota różdżka (Egmont 2017). Rezultaty badań Dybiec-Gajer stają się następnie asumptem do refleksji nad tradycją czytania i przekładania literatury dla dzieci w Polsce przy szczególnym uwzględnieniu polskojęzycznej recepcji baśni braci Grimm i związanego z nimi stereotypowego przekonania o ich szczególnym „okrucieństwie”.
\end{abstract}

1 E-mail: eliza.karminska@amu.edu.pl 
Abstract: Eliza Pieciul-Karmińska, SOME ASPECTS OF THE TRADITIONAL APPROACH TO READING AND TRANSLATING CHILDREN'S LITERATURE. BASED ON THE REVIEW OF JOANNA DYBIEC-GAJER'S BOOK: ZŁOTA RÓŻDŻKA - OD KSIĄŻKI DLA DZIECI PO DRESZCZOWIEC RACZEJ DLA DOROSŁYCH. "PORÓWNANIA" 1 (22), 2018. Vol. XXII, P. 383-397. ISSN 1733-165X. The paper is first of all a review of Joanna Dybiec-Gajer's book Złota różḋ̇ka - od książi dla dzieci po dreszczowiec raczej dla dorostych (2017) which discusses the translation and reception of the worldwide bestseller by Heinrich Hoffmann Struwwelpeter in Poland. Apart from this, a contemporary Polish adaptation of the German original is presented (Złota różḋka, Warsaw: Egmont 2017). Dybiec-Gajer's research, presented in the discussed book, opens up questions concerning reception and translation of (German) children's literature in Poland, including the Children's and Household Tales by Brothers Grimm, especially the concept of their "cruelty" which seems to be based on prejudice and results from lacking knowledge of the original fairy tales.

Niektóre rozprawy z zakresu przekładoznawstwa na tyle przypominają powieści detektywistyczne, że z powodzeniem mogą być czytane dla przyjemności przed snem. Do takich książek bez wątpienia zaliczyć można translatorskie rozważania Stanisława Barańczaka czy bestsellerowe dzieło Elżbiety Tabakowskiej O przekładzie na przykładzie (Kraków 2003), napisane na kanwie tłumaczenia Europy autorstwa Normana Daviesa. W tym kontekście warto także wspomnieć monografię Elżbiety Skibińskiej o francuskich przekładach Pana Tadeusza pt. Przekład a kultura (Wrocław 1999) czy książkę Marka Pieli pt. Grzech dosłowności we wspótczesnych polskich przekładach Starego Testamentu (Kraków 2003). Również najnowsze dzieło Joanny Dybiec-Gajer to chwalebny przykład, jak książka naukowa może być jednocześnie pasjonującą lekturą - i to nie tylko dla filologów czy przekładoznawców. Jednym głosem mówią o tym cytowane na okładce recenzentki tomu: Elżbieta Tabakowska i Maria Mocarz-Kleindienst, które zwracają uwagę, iż monografia o Złotej różdżce może być czytana także przez niefachowców, a nawet dzieci.

Warto w tym miejscu podkreślić niezwykłą staranność edycyjną Krakowskiego Towarzystwa Popularyzowania Wiedzy o Komunikacji Językowej „Tertium”. Pieczołowitość tego wydania: wysokiej jakości papier, niestandardowy format, twarda okładka, oryginalne ilustracje z licznych wydań Struwwelpetera i jego przekładów nie tylko usprawiedliwia wysoką cenę, lecz również sprawia, że książka ta spełnia równocześnie kilka istotnych celów. Czytelnik otrzymuje więc antologię tekstów: oryginalnych i tłumaczonych, a także tzw. "struwwelpetriad”, przy czym autorka zadbała, by teksty te odtworzone zostały w ich oryginalnej szacie graficznej. Zresztą namysł nad ilustracją odgrywa w recenzowanym tomie niepoślednią rolę. Niezwykle interesujący jest choćby przegląd ilustracji z epoki, który ujawnia zaskakujący fakt, że rosyjskie wydanie Struwwelpetera zatytułowane Stiopka Rastriopka wpłynęło wtórnie na autorskie ilustracje Heinricha Hoffmanna (Dybiec-Gajer 109 i nast.). Równie frapująca jest $\mathrm{w}$ tym względzie polonizacja rosyjskich ilustracji, gdy przykładowo bojarzy zyskują w polskim wydaniu sarmackie wąsy, rogatywkę i haftowaną sukmanę (Dybiec-Grajer 115). Z tych powodów książka może być traktowana 
również jako album. Równocześnie spełnia ona rolę kompendium - leksykonu wiedzy o oryginalnym dziele Heinricha Hoffmanna i jego międzynarodowej recepcji. Znajdziemy tutaj między innymi kalendarium (Dybiec-Grajer 182-186), bardzo pomocne Zestawienie tytułów wierszy z polskojęzycznych wydań Struwwelpetera $i$ jego naśladownictw z pierwowzorami (Dybiec-Grajer 187-191), a także komentowaną bibliografię nie tylko samej polskiej Złotej różdżki, ale i polskojęzycznej „struwwelpetriady" (Dybiec-Grajer 193-199), a całości encyklopedycznych informacji dopełniają smaczki w postaci reprodukcji znaczków pocztowych (Struwwelpeter wśród prekursorów komiksu na znaczkach pocztowych, Dybiec-Grajer 204-205).

Antologia, album, leksykon..., a przecież mówimy tutaj o monografii naukowej: o wyczerpującym i odkrywczym studium przekładoznawczym, które - jak to już zostało wspomniane - można czytać niemal jak pasjonującą powieść detektywistyczną. W rolę detektywa wciela się tu sama Autorka, której naukowe zasługi wykraczają daleko poza zgromadzenie i omówienie literatury przedmiotu oraz sformułowanie stosownych wniosków (co również czyni z powodzeniem). Wielką jej zasługą jest dotarcie do licznych źródeł i zrekonstruowanie ich w tekście ${ }^{2}$. Za tę filologiczną pracę u podstaw należą się Autorce szczególne podziękowania.

Równocześnie recenzowana książka przynosi fundamentalne odkrycia korygujące dotychczasową wiedzę o dziele Hoffmanna po polsku. Największe dokonania Autorki w tym zakresie to:

- wyjaśnienie wielu nieścisłości powielanych przez polskich badaczy3;

- dociekliwa próba jednoznacznego określenia autorstwa polskiego przekładu Struwwelpetera, a raczej jego adaptacji, bo tak należy rozumieć Złotą różdżkę;

- udowodnienie, że tekst polski powstał w oparciu o przekład rosyjski, a nie oryginalny tekst niemiecki;

- last, but not least, analiza porównawcza ukazująca, w jak dużym stopniu nasze wyobrażenia o dziele Hoffmanna są wynikiem przekładu, który na wielu poziomach niezgodny jest $\mathrm{z}$ intencją oryginału.

W warstwie przekładoznawczej Autorka porusza tyle ciekawych wątków i proponuje tak nowatorskie spojrzenie na Złota różdżkę, że chciałabym teraz bardziej szczegółowo zreferować treść książki, zwłaszcza kluczową część czwartą (Struwwelpeter - nowe życie w jezyku polskim).

W obszernym wprowadzeniu (Wstęp - 160 lat Złotej różdżki) przeczytamy charakterystykę oryginalnego dzieła, dzieje powstania i opis jego międzynarodowej recepcji. Zapoznamy się także z samym autorem, który - co może być zaskocze-

2 Chodzi tu o niezwykle ciekawe teksty z epoki: Kopciuszek dla grzecznych dzieci i Stuchaj rodziców i starszych.

3 Taką nieścisłością jest przypisywanie Kopciuszka dla grzecznych dzieci (1868), tekstu powstałego w ramach "struwwelpetriady", braciom Grimm, co równocześnie skutkuje uznawaniem daty publikacji tej wychowawczej książeczki za początek polskich tłumaczeń baśni Grimmów (por. Krysztofiak 151). 
niem dla polskiego czytelnika - nie miał w sobie nic z twórcy dydaktycznych wierszyków. Hoffmann był lekarzem w rodzinnym Frankfurcie nad Menem, a dzięki nowoczesnym jak na swój czas poglądom przyczynił się wydatnie do poprawienia sytuacji pacjentów z zaburzeniami psychicznymi.

Po prezentacji sylwetki Hoffmanna ${ }^{4}$ Autorka sygnalizuje zawiłą historię polskiego wydania, o której pisze, że jest „niezwykle frapująca i umożliwia prawdziwe odkrycia. To fascynujący przykład podróży utworu poprzez różne kultury, języki i epoki, w której kluczową rolę odegrali pospołu wydawcy, tłumacze i ilustratorzy" (Dybiec-Gajer 12).

Aby umożliwić czytelnikowi samodzielne śledzenie dziejów oryginału i jego tłumaczeń, trzy pierwsze części książki to antologia tekstów. W części pierwszej (Złota różdżka - czytajcie dzieci, uczcie się, jak to niegrzecznym bywa źle) pojawia się polskie wydanie tego tekstu z roku 1858 w oryginalnym kształcie, w części drugiej (Pierwowzory Złotej różdżki) - dwa wydania: niemiecki oryginał oraz rosyjski Stiopka Rastriopka (poprowadzone paralelnie, co pozwala na porównanie tekstów), a w części trzeciej polskojęzyczne Struwwelpetriady - wybrane teksty. To ponad 75 stron tekstów źródłowych - w oryginalnym kształcie i z oryginalnymi ilustracjami.

Szczególne podziękowania należą się tu za publikację enigmatycznego i niesłusznie przypisywanego braciom Grimm Kopciuszka dla niegrzecznych dzieci oraz za Stuchaj dorostych $i$ starszych ze zbiorów prywatnych. Dybiec-Gajer zaznacza przy tym, że

ta część nie ma charakteru bibliologicznej reedycji. Ma służyć udostępnieniu rzadkich tekstów i ilustracji w takiej konfiguracji, która ułatwi zrozumienie powstania i ewolucji utworów i zachęci do refleksji zarówno nad dziewiętnastowieczną literaturą dla dzieci i ówczesną kulturą tłumaczeniową, jak i nad współczesnym pojmowaniem roli literatury i przekładu dla najmłodszych (Dybiec-Gajer 14 i nast.).

Część czwarta zawiera historię Struwwelpetera w języku polskim i odnosi się do dwóch fundamentalnych, a dotąd pomijanych kwestii: autorstwa polskiego przekładu ${ }^{5}$ oraz jego źródła, którym bynajmniej nie jest tekst niemiecki.

Dybiec-Gajer docieka, czy tłumaczem Złotej różdżki, wydanej po raz pierwszy w roku 1858 przez Bolesława Maurycego Wolffa, jest rzeczywiście warszawski literat i dziennikarz Wacław Szymanowski (1821-1886), znajomy Cypriana Kamila

4 Zapoznajemy się także z jego portretem ( 1844 r. ze zbiorów Struwwelpeter-Museum). Warto w tym miejscu zaznaczyć, że Autorka jako badaczka związku ilustracji z tekstem w pełni wykorzystuje swoją wiedzę o warstwie graficznej tekstu i nasyca książkę obrazami, które poszerzają i uzupełniają nasze spojrzenie na problem. Nawet zamieszczenie portretów autora czy tłumacza odgrywa tu niepoślednią rolę.

5 Nazwisko tłumacza Złotej różdżki pojawiło się dopiero w wydaniu z roku 2003, opracowanym przez Janusza Dunina. 
Norwida, Teofila Lenartowicza i Bolesława Prusa. Bada więc jego styl oraz analizuje wspomnienia varsavianisty Juliusza Wiktora Gomulickiego, dokonując przy okazji kolejnego odkrycia: ustala mianowicie, że przypisywane Szymanowskiemu dzieło Dobre dziatki - dobre matki (1883) to tak naprawdę przekład książki Paula Thumanna Für Mutter und Kind (1881). Ponadto Autorka wskazuje, że różnice stylistyczne między Złotą różdżką a późniejszą o 25 lat książką Dobre dziatki - dobre matki mogłyby stanowić dowód, że Szymanowski nie był tłumaczem Złotej różdżki ${ }^{6}$. Jednak Autorka rzeczowo stwierdza, że dzisiaj nie jest możliwe jednoznaczne rozstrzygnięcie, czy Szymanowski był, czy nie był autorem Złotej różdżki ${ }^{7}$.

O wiele donioślejsze, a przy tym zaskakujące, jest wykazanie, że polskie wydanie nie opierało się na oryginale Hoffmanna, lecz na rosyjskiej edycji z roku 1849 pt. Stiopka Rastriopka ${ }^{8}$. To bardzo istotne odkrycie dla rozumienia polskiego tekstu, gdyż zasadniczo zmienia perspektywę badawczą, w której uwzględnić teraz trzeba wpływ rosyjskiego pierwowzoru na kształt tekstu polskiego. Istotne staje się tu przykładowo oddziaływanie carskiej cenzury, która za sprawą przekładu poprzez trzeci język wtórnie odcisnęła piętno na tekście polskim (i w paradoksalny sposób jest tam obecna do dzisiaj').

Przywołajmy tu anegdotyczny wręcz przykład: w oryginalnym wierszu o chłopcach wyśmiewających czarną skórę Maura jako instancja karząca pojawia się Święty Mikołaj, gdyż książeczka miała być prezentem bożonarodzeniowym dla syna Hoffmanna (stąd na ilustracjach choinka i inne akcenty świąteczne). Tłumacz rosyjski, bojąc się skojarzeń z carem Mikołajem, zamiast „der grosse Nikolas” pisze o „strasznym czarodzieju” („,ctрашный чародей”), który w polskim tekście staje się „,czarodziejem starym"... Autorka słusznie piętnując rozpowszechnione w polskim literaturoznawstwie bezkrytyczne utożsamianie Złotej różḋ̇ki z dziełem Hoffmanna,

6 Magdalena Samozwaniec w swych wspomnieniach przypisuje to tłumaczenie Władysławowi Ludwikowi Anczycowi.

7 Równocześnie koryguje błędną informację (cytowaną choćby w polskiej Wikipedii), że tłumaczem drugiego wydania Złotej różdżki (Warszawa 1922) jest Wacław Nowakowski. Ten błąd wynika prawdopodobnie $\mathrm{z}$ kontaminacji nazwisk tłumacza Wacława Szymanowskiego i ilustratora Bogdana Nowakowskiego.

8 Pod wpływem Stiopki oryginalny Struwwelpeter, czyli Piotrek (Rozczochraniec), staje się w polskim wydaniu Stasiem.

9 O zaskakujących wpływach carskiej cenzury na polskie współczesne przekłady przeczytać można w kontekście krytyki współczesnego przekładu Grimmów z roku 2012 (Wszystkie baśnie i legendy, Warszawa: REA), który został wykonany na podstawie rosyjskiego tekstu z końca XIX wieku. Odwaga braci Grimm sprzeciwiających się łamaniu konstytucji przez króla Hanoweru, która przeszła do historii jako protest tzw. „siedmiu z Getyngi”, zostaje wspomniana w rosyjskim wprowadzeniu do baśni z oczywistych powodów w sposób zawoalowany, gdyż cenzura carska nie mogła dopuścić do publikacji akcentów antymonarchicznych. Tymczasem współczesna tłumaczka ocenzurowaną przedmowę tłumaczy bezkrytycznie, a przecież „,W tekście, który został wydany ponad 100 lat później, w innym świecie i bez cenzury, powinno się znaleźć jakieś wyjaśnienie istotnego wydarzenia z życia braci Grimm, którzy w swojej ojczyźnie cenieni są także za ten odważny akt sumienia" (por. Pieciul-Karmińska 2013: 64). 
dostarcza w ten sposób dodatkowego argumentu: od teraz w omówieniach Złotej różdżki nie wolno nam abstrahować od jej rosyjskiego antenata. Zresztą utożsamianie przekładu z oryginałem, do czego Autorka ustosunkowuje się w rozdziale Perspektywa przekładoznawcza (Dybiec-Gajer 136 i nast.), jest jednym z poważniejszych, a równocześnie bardzo rozpowszechnionych błędów obecnych w krytyce literackiej. Dybiec-Gajer cytuje w swoim dziele polskich pisarzy i myślicieli (np. Czesława Miłosza), którzy na podstawie lektury Złotej różdżki formułują wnioski o tekście oryginalnym, chociaż tekstu niemieckiego nie znają.

Autorka dostarcza nam konkretnych argumentów, dlaczego tak czynić nie można, dowodząc zasadniczych różnic między tekstami oryginału i przekładu. To polski tłumacz okrasił bowiem wiersze pointami nieobecnymi w oryginale, kary spadające na bohaterów na kształt katastrof naturalnych przekształcił zaś w kary wymierzane przez rodziców, a nawet samego Pana Boga. Te analizy porównawcze, w których Autorka udowadnia dydaktyczną pasję polskiego tłumacza i wskazuje, jak bardzo mija się ona z zamiarem oryginału, o wiele bardziej zabawnego i mniej posępnego od polskiej wersji, to szczególnie istotny wkład Autorki nie tylko w badania nad polskim Struwwelpeterem, lecz również w debatę o przekładzie dla dzieci.

W swych bardzo skrupulatnych "analizach punktów krytycznych" Autorka jednoznacznie dowodzi, że morały, które najbardziej zapadają w pamięć i najbardziej kształtują perspektywę oglądu wierszyków (a takie wnioski wynikają na przykład z cytowanych wspomnień prominentnych czytelników Złotej różdżki, choćby Miłosza czy Tuwima), zostały w całości „dopisane w tłumaczeniu” (Dybiec-Gajer 149 i nast. $)^{10}$. Zatem jeśli krytykujemy dydaktyczny wydźwięk wierszyków, powinniśmy pamiętać, że krytykujemy zamysł Szymanowskiego, a nie Hoffmanna.

Obrazowym potwierdzeniem dydaktycznych intencji polskiego tłumacza jest choćby modyfikacja tytułu: oryginalny tytuł Struwwelpeter (Piotrek czupiradło), zawierający nazwę własną, która również w wydaniu rosyjskim pełni funkcję głównego tytułu i została zaadaptowana jako rymowana fraza Stiopka Rastriopka, funkcjonuje w polszczyźnie od ponad 160 lat jako Złota różdżka. Cytowany przez Autorkę Janusz Dunin wskazuje, że źródłem takiego kształtu tytułu jest (jakże wymowne!) nawiązanie do znanego wierszyka: „Rózeczką Duch Święty złe dziatki bić radzi, / różdżka bynajmniej zdrowiu nie zawadzi". Wybór cytatu właśnie z tego wiersza wiele mówi o intencjach tłumacza. Potwierdzają je dopisane morały oraz dodany już na samym wstępie dwuwiersz: „Czytajcie dzieci, uczcie się, / jak to niegrzecznym bywa źle", którego próżno by szukać w oryginale.

Dybiec-Gajer pokazuje, że wszystkie morały, w tym oczywiście te najbardziej znane i często zapamiętywane jako jedyne fragmenty utworów (np. „Kto nie je

10 Warto tutaj jeszcze wspomnieć o zupełnym wyrugowaniu bożonarodzeniowego przeznaczenia utworu widocznego tak w ilustracjach (choinka, prezenty), jak i w tekście (wspomniany Święty Mikołaj). 
zupy, ten umrzeć musi” czy „Bo kara Boża, tam gdzie swawola”), są nieobecne w oryginale. Sam Hoffmann w przedmowie do setnego wydania Struwwelpetera pisał, że "celowo unikał abstrakcyjnych z perspektywy dziecka morałów i sądów" (Dybiec-Gajer 150). Satyryczny oryginał piętnuje jedynie poprzez „wyolbrzymienie i przerysowanie". W oryginalnych tekstach bohaterowie wcale nie wyrażają skruchy czy żalu, tym samym nie zostają "poskromieni”, a dorośli bohaterowie nie tylko nie są wyniesieni na piedestał, lecz wręcz upokorzeni: „Rola i status dorosłych zostają nadwątlone także przez to, że nie wymierzają kar i wydają się bezsilni" (Dybiec-Grajer 151). Z tego względu książkę Hoffmanna często odczytuje się w nurcie antyautorytarnym.

Tymczasem polskie pointy nie pozostawiają wątpliwości co do dydaktycznego charakteru przesłania oraz - co bardzo ważne - roli dorosłych w wymierzaniu kary. Autorka ukazuje przykładowo, jak chłopiec ukarany przez demonicznego krawca obcięciem kciuków w polskiej wersji zostaje jeszcze dodatkowo pognębiony przez matkę, która odmawia mu ciastek. Równocześnie pojawia się tutaj inne ważkie przesunięcie wobec oryginału: $w$ wersji niemieckiej chłopiec traci palce, bo ssał kciuk - w wersji polskiej kara wynika z braku posłuszeństwa matce, a zatem rozważania o randze dyscypliny i posłuszeństwa są istotne tylko w odniesieniu do Złotej różdżki, a nie do Struwwelpetera, o czym więcej w dalszej części niniejszego tekstu.

\section{Współczesna Złota różḋ̇ka}

W tym miejscu wspomnieć należy o współczesnej adaptacji Złotej różdżki, czyli o publikacji wydawnictwa Egmont: Złota różdżka, czyli bajki dla niegrzecznych dzieci (2017). Tego wydania Autorka, jak sama zaznacza, nie zdążyła uwzględnić w analizach, chociaż zamieściła i omówiła ilustracje Joanny Sokołowskiej oraz przeprowadziła z nią wywiad (Dybiec-Gajer 166, 202 i nast.).

Współczesna Złota różdżka z pewnością doczeka się licznych omówień. Warto w tym miejscu podnieść kwestię kolejności edycyjnej, gdyż pierwsze były ilustracje Sokołowskiej ${ }^{11}$, a dopiero potem - na zamówienie wydawnictwa - powstały teksty. Ilustracje, barwne i zajmujące całe strony, znacząco wpływają na sposób odczytania tekstu, na przykład tytułowy wierszyk o chłopcu, który nie lubił się czesać, w oryginale spełnia rolę uwertury. To krótka rymowanka (w tekście tłumaczonym licząca osiem linijek), która z powodzeniem mieści się na jednej stronie, a na oryginalnej ilustracji pełni rolę epitafium wypisanego na cokole, na którym stoi rozczochrany Peter. Ten sarkastyczny żart (niegrzeczny chłopiec przedstawiony niczym figura pomnika) nie zostaje podjęty we współczesnej wersji, gdzie każdej linijce wiersza

11 Ilustracje Sokołowskiej pomyślane były oryginalnie jako praca dyplomowa i zostały wyróżnione w roku 2014 w konkursie „Książka dobrze zaprojektowana”. 
Piotruś Czupiradło w przekładzie Anny Bańkowskiej ${ }^{12}$ towarzyszy osobna, całostronicowa ilustracja. Wizualna lapidarność oryginału ustępuje narastającemu, wydłużonemu dramatyzmowi sekwencji ilustracji i „poszatkowanych” kolejnych wersów wierszyka.

Co ważne, wydawca w spisie treści lojalnie zaznacza, iż współczesne wiersze to "adaptacje”, wykonane przez grupę tłumaczy: Annę Bańkowską, Karolinę Iwaszkiewicz, Zuzannę Naczyńską, Adama Pluszkę i Marcina Wróbla. Zbiorowi nie patronuje zatem autorska wizja jednego tłumacza. Intencją wydania nie było filologicznie wierne odtworzenie dzieła oryginalnego $\mathrm{z}$ jego zakorzenieniem $\mathrm{w}$ miejscu i czasie. Mamy tu raczej do czynienia z wariacjami wokół znanych motywów i to wywodzących się raczej z wersji polskiej niż z oryginału.

Pobieżny ogląd tekstu pozwala wnioskować, że celem wydawcy była modernizacja Złotej różdżki, przeniesienie jej w dzisiejsze realia i zaadresowanie tekstu do współczesnych rodziców i dzieci. Wydaje się, że kluczową rolę odegrały w tym zamiarze ilustracje, w których obecne są współczesne motywy, na przykład blo$\mathrm{ku}$ z wielkiej płyty z charakterystycznymi balkonami, samolotu czy nowoczesnego plecaka, jakie dzieci noszą dzisiaj do szkoły. To właśnie ilustracje, jako pierwotne wobec tekstu, stały się "motorem” lokalizacji i aktualizacji. Także moje rozmowy z tłumaczami (Iwaszkiewicz, Wróblem, Bańkowską) potwierdzają ów całościowy zamiar, jakim jest uwspółcześnienie tekstu, czyli stworzenie takiej wersji Złotej różdżki, która będzie zrozumiała, a zwłaszcza atrakcyjna dla dzisiejszego polskiego odbiorcy.

Wszystko to z pewnością stanie się przedmiotem bardziej szczegółowych analiz translatorycznych, gdyż znaleźć tu można wdzięczny materiał do badań: oto oryginalny Święty Mikołaj (albo „czarodziej stary” z przekładu Szymanowskiego) to teraz "dozorca, pan Piotr" (tłum. Naczyńskiej), Hania-podpalaczka (w adaptacji Bańkowskiej) rozrabia na balkonie w bloku z wielkiej płyty, a niejadek Kacper (w adaptacji Wróbla) wygląda na ilustracji jak ofiara fastfoodów. Najbardziej symptomatycznym przykładem jest jednak „antyrasistowski” dopisek Naczyńskiej w wierszu Opowieść o małych czarnych chłopcach: „A sam Murzynek dopowiedział / coś, o czym dotąd nikt nie wiedział: / - Ja nigdy w Afryce nie byłem, / tutaj się, w Polsce, urodziłem". Z jednej strony, w świetle analiz Dybiec-Gajer dopisek taki wydaje się niezgodny z całościową, prześmiewczą intencją oryginału, z drugiej strony jest chwalony przez ilustratorkę, która sporządziła do tego wiersza sugestywną ilustrację czarnej dłoni z biało-czerwoną flagą na palcu wskazującym.

W kontekście omawianych tutaj przełomowych analiz Dybiec-Gajer z pewnością warto zbadać, na ile Złota różdżka AD 2017 bliższa jest tekstowi polskiemu niż niemieckiemu, zwłaszcza że niektóre przekłady bazowały na tekstach polskich i an-

12 Warto podkreślić, że Anna Bańkowska nawiązała w ten sposób do oryginalnego Struwwelpetera, a nie Stasia, który trafił do pierwotnej Złotej różḋ̇ki pod wpływem rosyjskiego Stiopki. 
gielskich jako wyjściowych, a pierwowzór niemiecki nie był traktowany jako sine qua non przekładu. We wspomnianym już wierszu o krawcu i chłopcu ssącym kciuk (a w wersji współczesnej obgryzającym paznokcie) pojawia się analogiczne do wersji Szymanowskiego wyakcentowanie posłuszeństwa, co sprawia, że przynajmniej w tym wypadku współczesny przekład bliższy jest Złotej różdżce niż Struwwelpeterowi: „Mama wróciła, a Konrad płacze. / - Chodź no tu, synku, niech no zobaczę, / czy grzeczny byłeś, czy posłuchałeś, / czy też paznokcie znów obgryzałeś?" (O Konradzie, co obgryzat paznokcie, adaptacja tekstu Wróbla).

Duże wątpliwości budzi z tego względu sprawa autorstwa - na okładce książki pojawia się nazwisko Hoffmanna, chociaż o wiele bliższa prawdy byłaby informacja, że jest to raczej dzieło "na motywach" lub "adaptacja”, a i tutaj - raczej adaptacja polskiego przekładu Szymanowskiego niż samego oryginału. Po lekturze książki Dybiec-Gajer takie przypisanie autorstwa Hoffmannowi wydaje się pochopne i nieuprawnione, zwłaszcza że wydawnictwo Egmont obdarzyło książkę tytułem Złota różdżka czyli bajki dla niegrzecznych dzieci, podczas gdy w podtytule oryginału nie ma nic o dzieciach grzecznych czy niegrzecznych: Der Struwwelpeter oder lustige Geschichten und drollige Bilder („Struwwelpeter albo zabawne historie i ucieszne obrazki").

Największe zdumienie budzą jednak refleksje Michała Rusinka, który we Wstępie bezrefleksyjnie utożsamia Złotą różdżkę Szymanowskiego z dziełem Hoffmanna:

Nieposłuszeństwo w świecie Hoffmanna to bowiem największa przewina. Tylko posłuszeństwo gwarantuje właściwy rozwój i przygotowuje do dorosłego życia, w którym też przecież nierzadko bywa cnotą, choćby wobec przełożonych... Wizja ta dość ponura i, miejmy nadzieję, archaiczna, ale na niej właśnie opiera się książka (Rusinek 5).

W ten sposób wstęp do współczesnego wydania Złotej różdżki staje się ilustracją "zaskakującej niefrasobliwości” współczesnych opracowań polonistycznych czy germanistycznych, o których Dybiec-Gajer pisze: „Chociaż podają, że mamy do czynienia z przekładem, wydają się utożsamiać niemiecki pierwowzór z polską wersją tekstu" (Dybiec-Gajer 136). Autorka stwierdza dobitnie, że takie traktowanie Złotej różdżki i Struwwelpetera jest „upraszczające i ahistoryczne” (Dybiec-Gajer 137). Ta kwestia domaga się tu bardziej szczegółowego omówienia, bo sprawa jest fundamentalna dla naszego sposobu rozumienia literatury obcojęzycznej.

\section{Kilka refleksji o przekładzie i recepcji literatury niemieckojęzycznej dla dzieci}

W podsumowaniu recenzji książki Dybiec-Gajer warto pokusić się o kilka uwag natury ogólnej, rozumianych jako polemika z pewną tradycją czytania i rozumienia nierodzimej literatury dziecięcej, dostępnej nam w przekładach. 
W recenzowanej monografii Dybiec-Gajer o dziele Hoffmanna znaleźć można wiele wątków, które pojawiają się także w polskich przekładach baśni braci Grimm oraz - co równie istotne - w ich polskojęzycznych omówieniach. Rodzi to intuicję, że $\mathrm{w}$ polskich przekładach oraz $\mathrm{w}$ polskojęzycznej recepcji obcej (zwłaszcza niemieckiej) literatury dziecięcej ${ }^{13}$ istnieją pewne wspólne i charakterystyczne tendencje, na podstawie których więcej niż o literaturze obcej powiedzieć można o naszej kulturze odbioru tekstów literackich, o kulturze wychowania dzieci i reagowania na obcość ${ }^{14}$.

Na początek warto raz jeszcze wspomnieć o istotnym fakcie przekładu Struwwelpetera na język polski poprzez język rosyjski. Co ciekawe, przez 150 lat nikt na to nie zwrócił uwagi. Wśród przekładów baśni Grimmów również odnajdziemy wydania sporządzone na podstawie wersji rosyjskich - i nie są to wcale wydania z XIX wieku, lecz z wieku XXI. W roku 2012 wydawnictwo REA wypuściło na rynek wspomniane już wyżej Wszystkie baśnie i legendy skrzętnie unikając informacji, co było źródłem przekładu.

Również inna obserwacja Dybiec-Gajer dotycząca Struwwelpetera zasługuje na szczególną uwagę: „Zaskakuje, że tak szeroko znane dzieło klasyki może być tak mało znane w kraju sąsiadującym z jego ojczyzną" (Dybiec-Gajer 13). Także badania polskojęzyczne poświęcone temu międzynarodowemu bestsellerowi są raczej ubogie - Autorka wymienia w tym kontekście tylko kilka nazwisk (m.in. Janiny Wiercińskiej czy Janusza Dunina). Podobnie w odniesieniu do badań nad Grimmami zaznaczyć trzeba, że zainteresowanie badaczy polskojęzycznych nazbyt często nie obejmuje treści i przesłania oryginału, a także badań niemieckojęzycznych ${ }^{15}$. W rezultacie większość krytyków opiera się na powielanych stereotypach o „okrucieństwie" tych tekstów, co zdradza brak znajomości oryginału.

13 Oczywiście Dybiec-Gajer już w tytule zaznacza, iż Struwwelpeter nie jest kierowany tylko do dzieci i może być czytany jako „dreszczowiec raczej dla dorosłych”, a baśnie Grimmów także obok adresata dziecięcego posiadały adresata dorosłego, co także sygnalizował oryginalny tytuł zbioru Kinderund Hausmärchen, który - dla utrzymania tej dwukierunkowości - przetłumaczyłam w moim przekładzie jako Baśnie dla dzieci i dla domu. Tutaj piszę jednak o „literaturze dziecięcej”, gdyż większość przeinaczeń przekładowych, a także negatywnych reakcji ze strony czytelników, wynika właśnie $\mathrm{z}$ faktu, że obydwa te teksty mierzone są miarą literatury kierowanej do dzieci i zgodnie $\mathrm{z}$ tym poddawane rozmaitym zabiegom (zwłaszcza dydaktyzacji i cenzurze).

14 Co ciekawe, nie dotyczy to tylko tekstów dawniejszych (choćby Grimmów czy E.T.A. Hoffmanna), lecz również współczesnych, przykładowo w polskim tłumaczeniu książki Paula Maara (rok wydania oryginału: 1973, rok wydania polskiego przekładu: 2009) odnotować można te same dydaktyczne tendencje jak w Złotej różdżce (por. Pieciul-Karmińska et al. 39 i nast.).

15 Spektakularnym przykładem jest tom Grimm - potęga dwóch braci (Kostecka 2013), w którym tylko jeden artykuł opiera się na niemieckojęzycznej literaturze przedmiotu, chociaż w sposób oczywisty właśnie w Niemczech prowadzone są intensywne badania nad spuścizną Grimmów i nadal dochodzi tam do spektakularnych odkryć. W publikacji tej znajdziemy także artykuły, których autorzy wyciągają wnioski o "językowym obrazie rodziny" lub "motywie wędrówki” w baśniach braci Grimm na podstawie polskojęzycznych cytatów, których próżno by szukać w oryginalnych tekstach, gdyż zostały dodane przez tłumaczy (por. Pieciul-Karmińska 2016: 78 i nast.). 
To właśnie tutaj ujawnia się wspomniana już wcześniej kwestia, która jest kluczowa dla badań nad literaturą „nierodzimą”, czyli nieuprawnione utożsamianie przekładu z oryginałem. Albowiem nie tylko „naiwni” czytelnicy sądzą, że czytany przez nich polski tekst jest identyczny z tekstem niemieckim i na tej podstawie wyciągają (zwykle negatywne) wnioski dotyczące oryginału.

Również badacze w krytycznych analizach nie zauważają, że pisząc o Złotej różdżce, piszą o wizji artystycznej, a właściwie pedagogicznej, Szymanowskiego a nie o koncepcji Hoffmanna obecnej w tekście zatytułowanym Struwwelpeter. Taki właśnie błąd we wstępie do współczesnej Złotej różdżki popełnia, jak wcześniej wspomniałam, Rusinek, który z podobną niefrasobliwością wywołuje temat „okrucieństwa bajek braci Grimm" (Rusinek 6). Takie chwytliwe, a jednak sztampowe i niezgodne z oryginałem powtarzanie, a co gorsza, utrwalanie stereotypów o wymogu „posłuszeństwa” czy o „okrucieństwie” niemieckojęzycznej literatury dla dzieci, deprecjonuje dzieło, niesprawiedliwie osądza autorów, razi powierzchownością i dowodzi nieznajomości oryginalnych tekstów.

Dybiec-Gajer jednoznacznie pokazała, że polski przekład Hoffmanna jest o wiele bardziej okrutny niż tekst niemiecki, który wcale nie lubuje się w opisywaniu szczegółów kary, jest raczej reporterski niż dramatyczny, a jego ostateczny wydźwięk bywa dwuznaczny. To polska Złota różdżka wprowadza do tekstu zarówno przejawy okrucieństwa, jak i wymóg bezwzględnego posłuszeństwa, karzącą instancją czyni zaś rodziców, a ostatecznie samego Pana Boga.

W polskojęzycznej recepcji utrwalił się i rozpowszechnił pogląd o „niemieckim okrucieństwie" w literaturze dla dzieci. Tymczasem krytyczne analizy translatoryczne pokazują, że polski czytelnik (a nierzadko i badacz) formułuje takie opinie w oparciu o rodzime przekłady, które te ponure wątki wzmacniają lub wręcz dopisują. Przypomina to klasyczną projekcję psychologiczną: polski czytelnik (badacz) krytykuje niemieckiego autora za okrucieństwo bądź wymóg posłuszeństwa i oskarża (niemiecki) oryginał o coś, co do tekstu wprowadziła polska tradycja. Tymczasem to polski przekład jest bardziej okrutny i moralizatorski od oryginału. Można wręcz odnieść wrażenie, że badania nad recepcją literatury niemieckojęzycznej więcej mówią nam o nas samych niż o tekstach oryginalnych.

Z obserwacji dotyczących między innymi recepcji baśni braci Grimm czy E.T.A. Hoffmanna w Polsce wynikają identyczne wnioski: autorzy polskich omówień czy krytycznych analiz wybranych aspektów dzieł obcojęzycznych pochopnie zakładają wierność przekładu i zrównują polskie tłumaczenia z oryginałami. Może tak czynić czytelnik (nawet tak wybitny jak Miłosz ${ }^{16}$ ), ale nie powinien tego robić literaturoznawca, nawet jeśli pisze tylko krótki wstęp do popularnego wydania.

16 Dybiec-Gajer przytacza in extenso jego krytykę Złotej różdżki i automatycznie Hoffmanna: „No macie tę cywilizację dzieci tak wychowanych, w karności i posłuszeństwie. Ona dała nam pierwszą wojnę światową, wzajemne mordowanie się w wojnie okopów, ona dała nam ślepe posłuszeństwo ludzi opętanych wiarą w wodza-szczurołapa w drugiej wojnie światowej" (Miłosz w: Dybiec-Gajer 130). 
W tym miejscu aż się prosi, by sformułować postulat pod adresem badaczy nierodzimej literatury dziecięcej: jeśli nie znamy języka oryginału, a pragniemy pisać o bestsellerach literatury światowej: o Grimmach, E.T.A. Hoffmannie, Heinrichu Hoffmannie czy Andersenie, sięgajmy przynajmniej po te polskojęzyczne teksty, które są wiarygodnymi przekładami tekstów obcojęzycznych. Na podstawie samego polskiego przekładu (często przekładu niewiernego, a nierzadko wykonanego przez trzeci język), bez porównania go $\mathrm{z}$ tekstem oryginału, nie można wyciągać wniosków o zamyśle oryginału, intencjach autora czy walorach artystycznych tekstu wyjściowego.

Przy okazji ujawnia się tutaj kolejna niezwykle ciekawa paralela między przekładami Grimmów a tłumaczeniem Hoffmanna oraz między ich krytycznymi omówieniami. Także w baśniach Grimmów kary wymierzane antagonistom są niemalże automatyczną konsekwencją naruszenia naturalnego porządku świata, a nie wynikiem zamierzonego działania ludzi żądnych zemsty. Antagoniści Grimmowscy nierzadko sami określają swoją karę ${ }^{17}$. Jest ona bezpośrednim skutkiem ich zachowania, na przykład zły wilk w drugiej części Czerwonego Kapturka ginie wskutek swojej zachłanności, topiąc się w studni. Wspomniane już, nierzadkie w polskim namyśle, głosy o okrucieństwie czy wręcz sadyzmie Grimmów zupełnie ignorują ten fakt, gdyż prawdopodobnie opierają się na polskich tłumaczeniach, które ów istotny aspekt wypaczają. A przecież z rzekomym okrucieństwem Grimmów rozprawiła się już trzy dekady temu wybitna badaczka folkloru Dorota Simonides, która pisze tak: „....cechy przypisywane bajkom Grimmów są immanentnymi cechami każdej ludowej bajki. Wystarczy w tym celu przejrzeć nasze zbiory bajek ludowych, aby nabrać przekonania, iż Grimmowie wyraźnie złagodzili swoje bajki" (Simonides 50).

Z podobnymi uprzedzeniami walczy Hubert Orłowski we wstępie do nowego przekładu baśni:

Dziś, po długich i jakże burzliwych sporach wokół wyjątkowego charakteru baśni braci Grimm, ich rzekomo „niemieckiego" okrucieństwa oraz natrętnego dydaktyzmu, rozczytujemy się w zebranych i opracowanych przez braci Wilhelma i Jacoba przekazach na szczęście bez uprzedzeń (Orłowski 9).

Jest to niezwykle ważne, gdyż stereotypowe przypisywanie Grimmom okrucieństwa prowadzi do nieuprawnionych i krzywdzących wniosków. Dwie autorki, Irena Koźmińska i Elżbieta Olszewska, znane dzięki opiniotwórczej Fundacji „Cała Polska czyta dzieciom”, w książce Wychowanie przez czytanie twierdzą, że baśnie

17 Podobny zamysł odnajdziemy w tekstach biblijnych, np. król Dawid sam wyznacza sobie wymiar kary, gdy w rozmowie z prorokiem Natanem, uznaje, że człowiek obciążony winą, jakiej dopuścił się on sam, powinien zostać ukarany śmiercią (por. $2 \mathrm{Sm}, 12$ ). 
braci Grimm są "taką samą trucizną przekazywaną z pokolenia na pokolenie jak klapsy i kary cielesne" (Koźmińska, Olszewska 118). Co ciekawe, dla Koźmińskiej i Olszewskiej tylko teksty Grimmów są ucieleśnieniem potępianych przez nie „baśni okrutnych", gdyż już artystyczne baśnie Andersena, które często zawierają przecież o wiele drastyczniejsze treści, są zalecane przez autorki dla dzieci w wieku od 4 do 6 lat, gdyż „należą do światowej klasyki literatury dla dzieci” (Koźmińska, Olszewska 265). Trudno oprzeć się wrażeniu, że także w tym wypadku zadziałały wspomniane przez Orłowskiego uprzedzenia, które autorki wzmocniły swym autorytetem wynikającym z działalności Fundacji „Cała Polska czyta dzieciom”.

Opisane przez Dybiec-Gajer dzieje polskiego przekładu Struwwelpetera wiele mówią nam także o samej literaturze dla dzieci, która ze względu na swój pośledni status - jak wskazała niegdyś Zohar Shavit (1986) - jest tłumaczona inaczej niż literatura dla dorosłych. Ponadto dydaktyczne zapędy dorosłych prowadzą do okaleczenia dzieła. Jak to dobitnie sformułował Grzegorz Leszczyński w książce Wielkie małe ksiażki:

Gwałt na literaturze, polegający na instrumentalnym traktowaniu utworu literackiego, ograniczaniu jego wartości do realizowania funkcji wychowawczych czy kształcących, zabija czytelnictwo, jest ogniem podłożonym pod bibliotekę przez owładniętego szaleńczą pasją... jej kapłana (Leszczyński 22).

Wszystko to skłania do wniosku, że nadszedł czas na taki przekład Struwwelpetera, który uczyniłby zadość oryginalnym intencjom i przewrotnej dwuznaczności niemieckich wierszyków. Współczesnej adaptacji Złotej różdżki wydawnictwa Egmont bliżej jest mimo wszystko do wersji Szymanowskiego aniżeli do Hoffmanna - choćby z racji zamierzonej lokalizacji i polonizacji tekstu. Przekładem, który stara się odtworzyć pierwotny zamiar artystyczny oryginału (także z racji niezmienionej warstwy graficznej), jest dwujęzyczna edycja wydawnictwa Tintenfass z Heidelbergu pt. Piotruś Rozczochraniec. Wesołe historyjki i zabawne rysunki w przekładzie Lecha Konopińskiego (Heidelberg 2015). Dzięki temu wydaniu czytelnik ma szansę lepiej poznać kulturę wyjściową oraz doświadczyć estetycznej wartości dzieła oryginalnego, równocześnie jednak przekład ten jest mało znany i prawie niedostępny w Polsce.

Nadszedł już także czas, by przestać powielać stereotypy, zwłaszcza ten o okrucieństwie niemieckojęzycznej literatury dla dzieci, którego niechlubne źródło znajdziemy w oficjalnej propagandzie PRL-u z przełomu lat czterdziestych i pięćdziesiątych XX wieku ${ }^{18}$. Zwłaszcza w odniesieniu do baśni braci Grimm można odnieść wrażenie, że w Polsce posiedliśmy jakąś tajemną wiedzę o ich szkodliwości (por.

18 Natalia Kuc przywołuje liczne przykłady z ówczesnej prasy, w których bez problemu zrównywano wątek spalonej wiedźmy w Jasiu i Małgosi z krematoriami w Auschwitz (por. Kuc 39 i nast.). 
przywołane rozważania Koźmińskiej i Olszewskiej). Widać to było zwłaszcza w jubileuszowym roku 2012, gdy w Niemczech świętowano dwustulecie pierwszego wydania zbioru Kinder- und Hausmärchen. $\mathrm{Z}$ tej okazji ukazało się wiele okolicznościowych publikacji i ważnych dzieł naukowych (między innymi nowa biografia Jakuba i Wilhelma Grimmów autorstwa Steffena Martusa czy dogłębne studium o informatorach braci napisane przez wybitnego grimmologa Heinza Röllekego), a w Kassel, mieście pierwszego wydania baśni, odbył się międzynarodowy kongres. Wśród prawie stu referatów wygłoszonych przez badaczy ze wszystkich kontynentów w ani jednym tytule nie znajdziemy słowa "okrucieństwo" (por. Brinker-von der Heyde), a wszyscy mówcy zgodnie podkreślali epokowe znaczenie tego „niemieckiego kompendium europejskiej bajki ludowej" (Simonides 42). Tymczasem polscy publicyści skupiali się - jak zwykle - na „okrucieństwie”. Adam Krzemiński z tej okazji pisał w Polityce:

Kto z dorosłych sięgnie dziś do oryginalnych „Baśni dla dzieci i dla domu” braci Grimm, ten będzie poruszony orgią okrucieństwa. $W$ jednej z baśni ojciec odrąbuje ręce własnej córce. W drugiej dziewczynka tańczy w rozpalonych do czerwoności trzewiczkach ${ }^{19}$. $\mathrm{W}$ trzeciej chłopiec nocą na cmentarzu uczy się, co to strach. W jeszcze innych jedna macocha truje swą pasierbicę, a druga każe córkom okaleczyć sobie stopy... Wszędzie krew, gwałt i śmierć (Krzemiński).

A przecież w ostatnich latach, przede wszystkim za sprawą poznańskiego wydawnictwa Media Rodzina, ukazało się wiele nowych przekładów klasyki dziecięcej, które przyniosły nowe spojrzenie na pozornie dobrze znany kanon.

Wracając do recenzowanego dzieła Dybiec-Gajer, podkreślić trzeba, że w świecie, w którym "alternatywne fakty” zastępują rzeczywistość, szczególne znaczenie mają rzetelne i merytoryczne analizy, docieranie do źródeł oraz weryfikacja stereotypów. Bierzmy więc przykład z krakowskiej badaczki.

\section{BIBLIOGRAFIA}

Brinker-von der Heyde Claudia et al. 200 Jahre Kinder- und Hausmärchen der Brüder Grimm. Kongressband. Frankfurt a. M.: Peter Lang Verlag, 2015.

Hoffmann, Heinrich. Piotruś Rozczochraniec. Wesołe historyjki i zabawne rysunki. Przeł. Lech Konopiński. Heidelberg: Edition Tintenfass, 2015.

Hoffmann, Heinrich. Złota różdżka, czyli bajki dla niegrzecznych dzieci. Przeł. Anna Bańkowska, Karolina Iwaszkiewicz, Zuzanna Naczyńska, Adam Pluszka, Marcin Wróbel. Warszawa: Egmont, 2017.

19 Autor na dowód tezy o drastyczności motywów Grimmowskich mylnie przywołuje baśń Andersena pt. Czerwone buciki (tak brzmi tytuł w przekładzie Sochańskiej). 
Dybiec-Gajer, Joanna. Złota różdżka - od książki dla dzieci po dreszczowiec raczej dla dorostych. Kraków: Tertium 2017.

Kostecka Weronika, red. Grimm - potęga dwóch braci. Kulturowe konteksty Kinder- und Hausmärchen. Warszawa: ASPRA-JR, 2013.

Koźmińska Irena, Olszewska Elżbieta. Wychowanie przez czytanie. Warszawa: Świat Książki, 2010. Krysztofiak, Maria. Przekład literacki a translatologia. Poznań: Wydawnictwo Naukowe UAM, 1999. Krzemiński, Adam. „Te straszne baśni braci Grimm. Czy bać się braci Grimm?”. Polityka 51 (2012). Web. 12.09.2018. <https://www.polityka.pl/tygodnikpolityka/kraj/1533939,1,te-straszne-basnie-bracigrimm.read>

Kuc, Natalia. „Bracia Grimm na ławie oskarżonych. Z problemów recepcji”. Grimm - potęga dwóch braci. Kulturowe konteksty Kinder- und Hausmärchen. Red. W. Kostecka. Warszawa: ASPRA-JR, 2013. S. 39-46.

Leszczyński, Grzegorz. Wielkie mate książki. Poznań: Media Rodzina, 2015.

Martus, Steffen. Die Brüder Grimm. Eine Biographie. Reinbek bei Hamburg: Rowohlt, 2013.

Pieciul-Karmińska, Eliza. „«Niebieska broda», czyli dlaczego nie należy tłumaczyć baśni braci Grimm z języka rosyjskiego". Język - Komunikacja - Informacja 8 (2013). S. 58-77.

Pieciul-Karmińska, Eliza. „Polska seria przekładowa «Dziadka do Orzechów i Króla Myszy» E.T.A. Hoffmanna". Studia interkulturowe Europy Środkowo-Wschodniej 8 (2014). S. 56-87.

Pieciul-Karmińska, Eliza. „O konieczności polskiego przekładu pierwszego wydania Baśni dla dzieci i dla domu braci Grimm z lat 1812 i 1815". Rocznik Przekładoznawczy 11 (2016). S. 77-92.

Pieciul-Karmińska Eliza, Sommerfeld Beate, Fimiak-Chwiłkowska Anna. Przekład literatury dla dzieci między manipulacją a autonomicznością estetyczna. Poznań: Wydawnictwo Naukowe UAM, 2017.

Rölleke, Heinz. Es war einmal: Die wahren Märchen der Brüder Grimm und wer sie ihnen erzählte. Frankfurt a. Main: Eichborn, 2011.

Rusinek, Michał. „Wstęp”. Heinrich Hoffmann. Złota różdżka, czyli bajki dla niegrzecznych dzieci. Warszawa: Egmont, 2017. S. 5-6.

Simonides, Dorota. „J. i W. Grimmowie a folklor polski”. Bracia Grimm i folklor narodów stowiańskich. Red. M. Czurak, J. Śliziński. Wrocław: Ossolineum, 1989. S. 25-50.

Shavit, Zohar. Poetics of Children's Literature. London: Athens Georgia, 1986. 
